\title{
Perbandingan Konsep Anjak Piutang Syariah DSN-MUI dan Konsep Akad Hiwalah Dalam Surat Edaran Bank Indonesia
}

\author{
Baerin Octaviani \\ Fakultas Syariah UIN Maulana Malik Ibrahim Malang \\ rierin_elvhiyani@yahoo.com
}

\begin{abstract}
:
The purpose of this study is to discover the concept of sharia factoring in fatwa of DSN-MUI with the concept of Hiwalah contract in Bank Indonesia Circular Letter as well as the similarities and the differences between the concept of sharia factoring in fatwa of DSN-MUI with the concept of Hiwalah contract in Bank Indonesia Circular Letter. This study uses normative juridical research with conceptual approach and statute approach. The concept of sharia factoring in fatwa of DSN-MUI uses wakalah bil ujrah, and the concept of Hiwalah contract in Bank Indonesia Circular Letter is the concept of debt transfer with Hiwalah muthlaqah and Hiwalah muqayyadah. There are similarities between the concept of sharia factoring in fatwa of DSN-MUI with the concept of Hiwalah contract in Bank Indonesia Circular Letter. Those are from the aspect definition, object, other types, agreement form to give a bailout (qardh) and get ujrah/fees, and its term in the Civil Code is cessie and subrogation. While the differences between the concept of sharia factoring in fatwa of DSN-MUI with the concept of Hiwalah contract in Bank Indonesia Circular Letter are the form of debt transfer and receivable transfer, the assignor, related institutions, object of transaction, and the differences with Hiwalah muqayyadah are not provide bailout and get ujrah, as well as the settlement of dispute.
\end{abstract}

Tujuan dari penelitian ini adalah untuk menemukan konsep anjak syariah di fatwa DSN-MUI dengan konsep kontrak Hiwalah dalam Surat Edaran Bank Indonesia serta persamaan dan perbedaan antara konsep anjak syariah di fatwa DSN-MUI dengan konsep kontrak Hiwalah dalam Surat Edaran Bank Indonesia. Penelitian ini menggunakan penelitian yuridis normatif dengan pendekatan konseptual dan pendekatan undang-undang. Konsep anjak syariah di fatwa DSN-MUI menggunakan wakalah bil ujrah, dan konsep kontrak Hiwalah dalam Surat Edaran Bank Indonesia adalah konsep transfer utang dengan Hiwalah muthlaqah dan Hiwalah muqayyadah. Ada kesamaan antara konsep anjak syariah di fatwa DSNMUI dengan konsep kontrak Hiwalah dalam Surat Edaran Bank Indonesia. Mereka adalah dari definisi aspek, objek, jenis lainnya, bentuk kesepakatan untuk memberikan bailout (qardh) dan mendapatkan ujrah / biaya, dan jangka dalam KUHPerdata adalah cessie dan subrogasi. Sedangkan perbedaan antara konsep anjak syariah di fatwa DSN-MUI dengan konsep kontrak Hiwalah dalam Surat Edaran Bank Indonesia adalah bentuk transfer utang dan pengalihan piutang, pemberi tugas, instansi terkait, objek transaksi, dan perbedaan dengan Hiwalah muqayyadah tidak memberikan bailout dan ujrah, serta penyelesaian sengketa.

Kata Kunci: anjak piutang; DSN-MUI; hiwalah 


\section{Pendahuluan}

Manusia tidak bisa lepas dari kegiatan akad atau transaksi dengan sesama. Di antara transaksi yang populer di kalangan manusia adalah jual beli. Jual beli merupakan kegiatan transaksi dalam bidang bisnis demi kebutuhan dan kelangsungan hidup manusia. Jual beli dapat didefinisikan sebagai pertukaran harta atas dasar saling suka rela atau memindahkan milik dengan ganti yang dapat dibenarkan. ${ }^{1}$ Sistem jual beli yang ada di masyarakat dalam hal pembayaran dapat dilakukan dengan dua cara, yaitu secara tunai dan secara kredit atau angsuran. Jual beli kredit atau angsuran (Bai'u At-Taqsith) yaitu suatu pembelian yang dilakukan terhadap suatu barang yang mana pembayaran harga barang tersebut dilakukan secara berangsur-angsur sesuai dengan tahapan pembayaran yang telah disepakati kedua belah pihak yakni penjual dan pembeli. ${ }^{2}$ Jual beli secara angsuran banyak dilakukan oleh kalangan masyarakat untuk memenuhi kebutuhan hidupnya terhadap kebutuhan konsumtif. Selain dengan cara angsuran, jual beli juga dilakukan dengan cara berhutang terlebih dahulu kepada pembeli yang kemudian pembayarannya dilakukan secara cicilan. Kegiatan jual beli tidak hanya dilakukan oleh kalangan masyarakat, namun di lingkungan perusahaan juga melakukan kegiatan jual beli dalam bentuk perdagangan barang atau jasa. Pada umumnya, setiap perusahaan memiliki suatu aktivitas operasional perusahaan. Perusahaan harus mengelola aktivitas dalam melakukan penjualan barang atau jasa baik dilakukan secara tunai maupun kredit agar pengelolaan tersebut berjalan dengan baik. Apabila transaksi pembayaran dilakukan secara tunai, maka perusahaan akan langsung menerima keuntungan secara tunai. Sedangkan apabila transaksi dilakukan secara kredit, maka perusahaan akan mempunyai piutang dari pihak lain sehingga sumber pendapatan perusahaan belum terbayarkan. Apabila dalam penagihan piutang dagang kepada pihak lain mengalami kemacetan, maka secara otomatis perusahaan mengalami kerugian. Sehingga solusinya adalah pihak perusahaan akan mengalihkan atau menjual piutangnya kepada pihak lain atau kepada lembaga yang memberikan jasa pengalihan piutang .

Adapun lembaga yang memberikan jasa pengalihan piutang yaitu lembaga pembiayaan. Menurut Peraturan Presiden Nomor 9 Tahun 2009 tentang Lembaga Pembiayaan, lembaga pembiayaan adalah badan usaha yang melakukan pembiayaan dalam bentuk penyediaan dana atau barang modal. ${ }^{3}$ Lembaga pembiayaan meliputi perusahaan pembiayaan, perusahaan modal ventura, dan perusahaan pembiayaan infrastruktur Menurut Peraturan Menteri Keuangan Nomor. 84/PMK.012/2006, badan usaha di luar bank dan lembaga keuangan bukan bank yang khusus didirikan untuk melakukan kegiatan yang termasuk lembaga pembiayaan disebut Perusahaan Pembiayaan. ${ }^{4}$ Kegiatan usaha yang merupakan bagian dari perusahaan pembiayaan di antaranya sewa guna usaha (leasing), anjak piutang (factoring), usaha kartu kredit dan pembiayaan konsumen. Salah satu kegiatan usaha dari perusahaan pembiayaan yang memberikan jasa pengalihan piutang adalah anjak piutang (factoring). Anjak piutang (factoring) didefinisikan sebagai kegiatan pembiayaan dalam bentuk pembelian piutang dagang jangka pendek suatu perusahaan berikut pengurusan atas piutang tersebut. ${ }^{5}$ Sedangkan perusahaan anjak piutang merupakan lembaga yang memberikan jasa pengalihan piutang, yaitu perusahaan yang kegiatannya

\footnotetext{
${ }^{1}$ Sayyid Sabiq, Fikih Sunnah (Bandung: Al-Ma'arif, 1987), 45.

2 Chairuman Pasaribu and Suhrawardi K Lubis, Hukum perjanjian dalam Islam (Jakarta: Sinar Grafika, 2004), 50.

${ }^{3}$ Pasal 1 ayat 1 Peraturan Presiden Nomor. 9 Tahun 2009 tentang Lembaga Pembiayaan

${ }^{4}$ Pasal 1 huruf b Peraturan Menteri Keuangan Nomor. 84/PMK.012/2006 tentang Perusahaan Pembiayaan

${ }^{5}$ Pasal 1 ayat 6 Peraturan Presiden Nomor. 9 Tahun 2009 tentang Lembaga Pembiayaan
} 
melakukan penagihan atau pembelian, pengambilalihan atau pengelolaan hutang piutang suatu perusahaan dengan imbalan atau pembayaran tertentu milik perusahaan. ${ }^{6}$

Adanya perusahaan pembiayaan yang memberikan jasa pengalihan piutang dengan konsep anjak piutang (factoring) bertujuan untuk memberikan kemudahan bagi perusahaan untuk menyelesaikan piutangnya tersebut terkait dengan transaksi penjualannya secara kerdit, di samping itu, agar terhindar dari risiko yang tidak diharapkan serta tidak merasa dirugikan karena adanya wanprestasi dari pihak lain atau debitur. Selain dipraktikkan di perusahaan pembiayaan konvensional, anjak piutang juga dipraktikkan di perusahaan pembiayaan yang berdasarkan prinsip syariah. Konsep anjak piutang (factoring) yang berdasarkan prinsip syariah sering dikatakan sama dengan istilah hiwâlah, karena secara operasional mirip dengan pelaksanaan hiwâlah di perbankan syariah. Perjanjian pengalihan piutang atau anjak piutang (factoring) dalam fiqh muamalah disebut dengan istilah hiwâlah. ${ }^{7}$ Akan tetapi, hal ini sangat bertentangan dengan yang diatur dalam Fatwa Dewan Syariah Nasional (DSN) Majelis Ulama Indonesia (MUI) Nomor 67 Tahun 2008 tentang Anjak Piutang Syariah. Dalam Fatwa DSN-MUI Nomor. 67 Tahun 2008 tentang Anjak Piutang ditegaskan bahwa akad yang dapat digunakan dalam anjak piutang secara syariah adalah wakâlah bil ujrah. ${ }^{8}$

Wakâlah atau wikâlah berarti penyerahan, pendelegasian, atau pemberian mandat. Dalam bahasa arab hal ini dapat dipahami sebagai at-Tafwîd. Akan tetapi yang dimaksud sebagai al-wakâlah karena manusia membutuhkannya. Tidak setiap orang mempunyai kemampuan atau kesempatan untuk menyelesaikan segala urusan sendiri. Pada suatu waktu, seseorang perlu mendelegesikan suatu pekerjaan kepada orang lain untuk mewakili dirinya. ${ }^{9}$ Sedangkan akad hiwâlah yang menjadi salah satu produk jasa perbankan syariah memiliki definisi yaitu pengalihan utang dari orang yang berhutang kepada orang lain yang wajib menanggungnya. Dalam istilah Islam merupakan pemindahan beban hutang dari muhîl (orang yang berutang) menjadi tanggungan muhâl 'alaih atau orang yang berkewajiban membayar hutang. ${ }^{10}$ Tujuan hiwâlah adalah membantu pemasok mendapatkan modal modal tunai agar dapat melanjutkan produksinya, karena ia memiliki piutang usaha sebelum dibayar oleh pembeli sehingga tidak memiliki cukup dana untuk memulai pekerjaan berikutnya. Landasan yang dapat dijadikan dasar akad hiwâlah yaitu terdapat dalam sebuah hadits riwayat al-Bukhari:

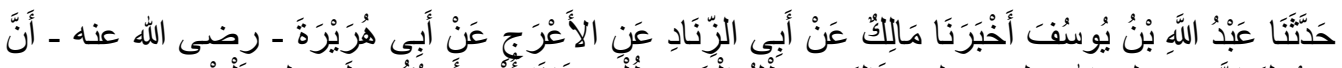

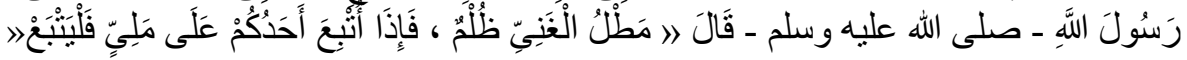

Artinya: "Menunda pembayaran bagi yang mampu adalah kezaliman. Dan jika seorang dari kamu diikutkan (di-hawalah-kan) kepada orang yang mampu, maka ikutilah."11

Pada hadis ini tampak bahwa Rasulullah memberitahukan kepada orang yang menguntungkan, jika orang yang berhutang menghiwalahkan kepada orang yang kaya atau mampu, hendaklah ia menerima hiwâlah tersebut dan hendaklah ia menagih kepada orang yang meng hiwâlahkan (muhâl alaih). Dengan demikian haknya terpenuhi. Konsep akad hiwâlah dalam perbankan syariah diatur dalam SEBI Nomor. 10/14/DPBS disebutkan bahwa salah satu produk jasa perbankan syariah adalah hiwâlah. Menurut SEBI tersebut,

\footnotetext{
${ }^{6}$ Kasmir, Bank \& Lembaga Keuangan Lainnya (Jakarta: RajaGrafindo Persada, 2005), 286-287.

${ }^{7}$ Burhanuddin S, Hukum Kontrak Syariah (Yogyakarta: BPFE-Yogyakarta, 2009), 75.

${ }^{8}$ Burhanuddin S, Aspek hukum lembaga keuangan syariah (Yogyakarta: Graha Ilmu, 2010), 198.

${ }^{9}$ M. Nur Rianto Al Arif, Dasar-Dasar Pemasaran Bank Syariah (Jakarta: IBFIM, 2010), 40.

${ }^{10}$ Al Arif, Dasar-Dasar Pemasaran Bank Syariah, 67.

${ }^{11}$ Muhammad bin Isma'il al-Bukhari, Shahih al-Bukhari, Jilid 8 (Beirut: Dar al-Fikr, 2002), 325.
} 
pemberian jasa pengalihan utang atas dasar hiwâlah terdiri atas hawâlah muthlaqah dan hawâlah muqayyadah. Hawâlah muthlaqah ialah transaksi yang berfungsi untuk pengalihan utang dari pihak yang menimbulkan adanya dana keluar (cash out) bank. Hawâlah muqayyadah ialah transaksi yang berfungsi untuk melakukan set off (penyelesaian) utang piutang diantara tiga pihak yang memiliki hubungan muamalah (hutang piutang) melalui transaksi pengalihan utang serta tidak menimbulkan adanya dana keluar (cash out).12 Dengan demikian, anggapan bahwa konsep anjak piutang yang berdasarkan syariah bukanlah menggunakan akad hiwâlah melainkan menggunakan akad wakâlah bil ujrah karena akad hiwâlah dan akad wakâlah merupakan akad yang berbeda.

Mengacu pada uraian di atas dapat ditegaskan bahwa terkait dengan pengalihan piutang yakni dapat dilakukan dengan konsep anjak piutang syariah dalam Fatwa DSNMUI yang menggunakan prinsip wakâlah bil ujrah dengan konsep akad hiwâlah dalam Surat Edaran Bank Indonesia, dinyatakan bahwa terdapat persamaan dan perbedaan konsep anjak piutang syariah dalam Fatwa DSN-MUI yang menggunakan prinsip wakâlah bil ujrah, maupun konsep akad hiwâlah dalam Surat Edaran Bank Indonesia. Dalam konteks penelitian hukum normatif, perbedaan tersebut memunculkan isu hukum, yaitu pertentangan hukum (conflict of norm). Menurut Peter Mahmud Marzuki isu hukum diawali karena masalah timbul karena adanya dua proposisi yang mempunyai hubungan, baik yang bersifat fungsional, kausalitas maupun yang satu menegaskan yang lainnya. Isu hukum juga timbul karena adannya dua proposisi hukum yang saling berhubungan satu terhadap lainnya.13 berdasarkan berbagai persoalan di atas, artikel ini bertujuan untuk mengetahui konsep anjak piutang syariah dalam Fatwa DSN-MUI dengan konsep akad hiwâlah dalam Surat Edaran Bank Indonesia. selain itu, penulis bertujuan untuk menggali persamaan dan perbedaan antara konsep anjak piutang syariah dalam Fatwa DSN-MUI dengan konsep akad hiwâlah dalam Surat Edaran Bank Indonesia.

\section{Metode Penelitian}

Jenis penelitian ini adalah penelitian hukum normatif. Penelitian hukum yang dilakukan dengan cara meneliti bahan pustaka atau data sekunder berkala dapat dikatakan dengan penelitian atau penelitian hukum normatif. ${ }^{12}$ Karena penelitian ini berupaya membandingkan konsep anjak piutang syariah dengan akad hiwâlah yang ditinjau dari peraturan Fatwa DSNMUI dengan Surat Edaran Bank Indonesia. penelitian ini menggunakan pendekatan konsep. untuk untuk memahami perbandingan antara konsep anjak piutang syariah dengan konsep akad hiwâlah. ${ }^{13}$ Selain itu penelitian ini menggunakan pendeketan perundang-undangan (statue approach) untuk menelaah semua peraturan perundang-undangan dan regulasi yang berkaitan dengan isu hukum yang sedang diteliti, yaitu konsep anjak piutang syariah dalam Fatwa DSN-MUI Nomor. 67 Tahun 2008 dengan konsep akad hiwâlah dalam Surat Edaran Bank Indonesia Nomor. 10/14/DPBS. ${ }^{14}$ Di samping itu, penulis juga menggunakan pendekatan perbandingan (comparative approach) untuk mengetahui perbandingan dari aturan fatwa DSN-MUI tentang anjak piutang syariah dengan aturan Surat Edaran Bank Indonesia tentang akad hiwâlah. ${ }^{15}$ Bahan hukum primer $^{16}$ penelitian ini terdiri atas: 1) Undang-Undang Nomor 21 Tahun 2008 tentang Perbankan Syariah. 2) Peraturan Menteri

12 Soerjono Soekanto and Sri Mamudji, Penelitian Hukum Normatif: Suatu Tinjauan Singkat (Jakarta: RajaGrafindo Persada, 2006), 13.

${ }^{13}$ Johnny Ibrahim, Teori Dan Metode Penelitian Hukum Normatif (Malang: Bayu Media Publishing, 2006), 306.

${ }^{14}$ Bahder Johan Nasution, Metode Penelitian Ilmu Hukum (Bandung: Mandar Maju, 2008), 92.

15 Peter Mahmud Marzuki, Penelitian Hukum (Jakarta: Kencana, 2010), 133.

${ }^{16}$ Marzuki, Penelitian Hukum, 138.

Jurisdictie: Jurnal Hukum dan Syariah Vol. 6 No. 2 Desember 2015 
Keuangan Nomor. 84/PMK.012/2006 tentang Perusahaan Pembiayaan 3) Peraturan Ketua Badan Pengawas Pasar Modal Dan Lembaga Keuangan Nomor: Per-03/bl/2007 tentang Kegiatan Perusahaan Pembiayaan Berdasarkan Prinsip Syariah. 4) SEBI Nomor. 10/14/DPBS, Jakarta 17 Maret 2008. Surat Edaran Kepada Seluruh Bank Syariah Di Indonesia, Perihal: Pelaksanaan Prinsip Syariah dalam Kegiatan Penghimpunan Dana dan Penyaluran Dana serta Pelayanan Jasa Bank Syariah. 5) Fatwa DSN-MUI Nomor: 67/DSNMUI/III/2008 tentang Anjak Piutang Syariah. Sedangkan bahan hukum sekundernya ${ }^{17}$ terdiri dari: a) Chairuman Pasaribu dan Suhrawardi, Hukum Perjanjian Dalam Islam, Jakarta: Sinar Grafika,2004; b) Nur Rianto, Dasar-Dasar Pemasaran Bank Syariah, Bandung: Afabeta, 2010; c) Sayyid Sabiq, Fiqh Sunnah, Bandung: Al-Ma'arif, 1987; d) Achmat Syafei Fiqh Muamalah, Bandung: Pustaka Setia, 2000; e) Kasmir, Bank \& Lembaga Keuangan Lainnya, Jakarta: PT Raja Grafindo Persada, 2005 f) Irma Devita Purnamasari, Suswinarno, Panduan Lengkap Hukum Praktisi Populer Kiat-kiat Cerdas, Mudah, dan Bijak Memahami Masalah Akad Syariah, Bandung: PT Mizan Pustaka, 2011; g) Burhanuddin, S, Hukum Kontrak Syariah, Yogyakarta: BPEE Yogyakarta, 2009; h) Burhanuddin, S, Aspek Hukum Lembaga Keuangan Syariah, Yogyakarta: Graha Ilmu, 2010; i) Andri Soemitro, Bank \& Lembaga Keuangan Syariah, Jakarta: Kencana, 2009.

\section{Hasil dan Pembahasan}

\section{Konsep Anjak Piutang Syariah dalam Fatwa DSN-MUI}

Pada awalnya perkembangan usaha anjak piutang di Indonesia belum begitu popular. Namun sejak adanya Keputusan Presiden Nomor 61 Tahun 1988 dan Keputusan Menteri Keuangan No. 1251/KMK.13/1988 tanggal 20 Desember 1988. Peraturan ini diterapkan untuk memberikan alternatif pembiayaan usaha dari berbagai macam jenis lembaga keuangan, termasuk perusahaan anjak piutang. Pembiayaan usaha tidak hanya diberikan keleluasaan untuk mengembangkan usaha dengan modal yang tidak hanya bersumber dari lembaga perbankan saja. Jasa anjak piutang dapat diberikan oleh suatu lembaga keuangan sebagai salah satu kegiatan usahanya yang secara khusus memberikan jasa anjak piutang yaitu sebagai pengalihan piutang. Setelah dikeluarkannya Keppres No. 61 Tahun 1988 tentang Lembaga Pembiayaan dan Keputusan Menteri Keuangan No. 1251/KMK.013/1988 tanggal 20 Desember 1988 tentang Ketentuan dan Tata Cara Pelaksanaan Lembaga Pembiayaan, kemudian disusun beberapa peraturan lain yakni di antaranya Keputusan Menteri Keuangan No. 448/KMK.017/2000 tentang Perusahaan Pembiayaan. Kemudian Keputusan Menteri Keuangan No. 172/KMK.06/2002 tanggal 23 April 2002 tentang Perusahaan Pembiayaan, dan terakhir Peraturan Menteri Keuangan No. 84/PMK.012/2006 tentang Peraturan Pembiayaan. Selain beberapa peraturan di atas, terdapat peraturan lain mengenai lembaga pembiayaan yang memberikan definisi anjak piutang, bahwa yang dimaksud anjak piutang (factoring) adalah kegiatan pembiayaan dalam bentuk pembelian piutang dagang jangka pendek suatu Perusahaan berikut pengurusan atas piutang tersebut. ${ }^{18}$

Dapat diketahui dari pengertian di atas, bahwa perusahaan anjak piutang merupakan perusahaan yang bergerak di bidang pengalihan piutang yang mana kegiatannya tidak hanya dilakukan dengan cara mengalihkan utang saja, akan tetapi dilakukan dengan cara pembelian serta pengurusan piutang yang berasal dari transaksi perdagangan jangka pendek baik dalam negeri maupun luar negeri. Adapun para pihak yang terlibat dalam kegiatan anjak piutang di antaranya yaitu perusahaan factoring, pihak penjual piutang (klien), dan nasabah. Mekanisme kegiatan anjak piutang diatur dalam Pasal 4 PMK No. 84/2006 dijelaskan sebagai berikut: ${ }^{19}$

(1) Kegiatan Anjak Piutang dilakukan dalam bentuk pembelian piutang dagang jangka pendek

\footnotetext{
${ }^{17}$ Marzuki, Penelitian Hukum, 155.

${ }^{18}$ Pasal 1 ayat 6 Peraturan Presiden Republik Indonesia Nomor. 9 Tahun 2009 Tentang Lembaga Pembiayaan

${ }^{19}$ Pasal 4 Peraturan Menteri Keuangan Nomor. 84/PMK.012/2006 Tentang Perusahaan Pembiayaan

Jurisdictie: Jurnal Hukum dan Syariah Vol. 6 No. 2 Desember 2015
} 
suatu perusahaan berikut pengurusan atas piutang dagang tersebut; (2) Kegiatan Anjak Piutang sebagaimana dimaksud pada ayat (1), dapat dilakukan dalam bentuk Anjak Piutang tanpa jaminan dari Penjual Piutang (without recourse) dan Anjak Piutang dengan jaminan dari Penjual Piutang (with recourse); (3) Anjak Piutang tanpa jaminan dari Penjual Piutang (without recourse) adalah kegiatan Anjak Piutang di mana Perusahaan Pembiayaan menanggung seluruh risiko tidak tertagihnya piutang; (4) Anjak Piutang dengan jaminan dari Penjual Piutang (with recourse) adalah kegiatan Anjak Piutang di mana Penjual Piutang menanggung risiko tidak tertagihnya sebagian atau seluruh piutang yang dijual kepada Perusahaan Pembiayaan; (5) Piutang dagang jangka pendek sebagaimana dimaksud pada ayat (1) adalah piutang dagang yang jatuh tempo selama-lamanya 1 (satu) tahun. Dengan demikian, adanya anjak piutang bertujuan menghindari terjadinya kredit macet dari pihak debitur yang akan mengakibatkan kerugian yang besar bagi pihak klien atau perusahaan klien, sehingga solusinya adalah pihak klien menjual piutang atau mengalihkan piutang kepada perusahaan factoring untuk memperlancar kegiatan penyelesaian utang piutang dan membantu pihak klien dalam mengelola penjualannya secara kredit agar teratur yang timbul dari transaksi perdagangan.

Konsep anjak piutang menurut Fatwa DSN-MUI merupakan konsep anjak piutang yang berdasarkan prinsip syariah, yang bertujuan untuk menghindari dari praktik yang dilarang oleh hukum Islam seperti riba, gharar, dan maisir. Hal ini juga memberikan kemudahan bagi para pelaku kegiatan anjak piutang untuk melaksanakan kegiatan anjak piutang berdasarkan prinsipprinsip syariah, sebagaimana dalam kaidah fiqh yang berbunyi: "Pada dasarnya, segala bentuk mu'amalat boleh dilakukan kecuali ada dalil yang mengharamkannya." Kaidah di atas, menunjukan bahwa kegiatan anjak piutang diperbolehkan selama tidak bertentangan dengan prinsip syariah. Maka dari itu, untuk menghindari dari hal-hal yang dilarang oleh syara', maka DSN-MUI mengeluarkan Fatwa DSN-MUI No. 67 Tahun 2008 tentang Anjak Piutang Syariah. Anjak piutang secara syariah yang diatur dalam Fatwa DSN-MUI No. 67 Tahun 2008 merupakan peraturan yang berdasarkan prinsip syariah dengan menggunakan akad wakâlah bil ujrah. Penggunaan akad wakâlah bil ujrah tersebut untuk membedakan anjak piutang syariah dengan anjak piutang konvensional. Adapun ketentuan akad dalam anjak piutang syariah yang diatur dalam Fatwa DSN-MUI yaitu sebagai berikut: ${ }^{20}$ (a) Akad yang dapat digunakan dalam Anjak Piutang Syariah adalah wakâlah bil ujrah; (b) Pihak yang berpiutang mewakilkan kepada pihak lain untuk melakukan pengurusan dokumen-dokumen penjualan kemudian menagih piutang kepada yang berutang atau pihak lain yang ditunjuk oleh pihak yang berutang; (c) Pihak yang ditunjuk menjadi wakil dari yang berpiutang untuk melakukan penagihan (collection) kepada pihak yang berutang atau pihak lain yang ditunjuk oleh pihak yang berutang untuk membayar; (d) Pihak yang ditunjuk menjadi wakil dapat memberikan dana talangan ( $q a r d h$ ) kepada pihak yang berpiutang sebesar nilai piutang; (e) Atas jasanya untuk melakukan penagihan tersebut, pihak yang ditunjuk menjadi wakil dapat memperoleh ujrah/fee; (f) Besar ujrah harus disepakati pada saat akad dan dinyatakan dalam bentuk nominal, bukan dalam bentuk presentase yang dihitung dari pokok piutang; (g) Pembayaran ujrah dapat diambil dapat diambil dari dana talangan atau sesuai kesepakatan dalam akad; (h) Antara akad wakâlah bil ujrah dan akad qardh, tidak dibolehkan adanya keterkaitan (ta'alluq).

Dalam obyek wakâlah haruslah sesuatu yang dapat dijadikan objek akad atau yang dapat dikerjakan orang lain, perkara-perkara yang mubah dan dibenarkan oleh syara', memiliki identitas yang jelas, serta milik sah dari almuwakkil. Misalnya, jual beli, sewa menyewa, pemindahan utang, tanggungan, kerja sama usaha, penukaran mata uang,

\footnotetext{
${ }^{20}$ Fatwa DSN-MUI No. 67/DSN-MUI/III/2008 tentang Anjak Piutang Syariah

Jurisdictie: Jurnal Hukum dan Syariah Vol. 6 No. 2 Desember 2015
} 
pemberian gaji, akad bagi hasil, perdamaian dan sebagainya. ${ }^{21}$ Atas dasar ketentuan di atas, maka anjak piutang menggunakan akad wakâlah bil ujrah karena di dalamnya terdapat suatu perwakilan yang mana pihak klien mewakilkan pengurusan maupun penagihan piutangnya kepada perusahaan factoring, sehingga perusahaan factoring melakukan urusan pihak klien dalam hal pengurusan dokumen-dokumen dan penagihan piutang kepada pihak yang berutang, sehingga hal itu diperbolehkan oleh syara'. Selain diatur dalam Fatwa DSN-MUI No. 67 Tahun 2008 tentang Anjak Piutang Syariah, anjak piutang secara syariah juga diatur dalam Peraturan Badan Pengawas Pasar Modal dan Lembaga Keuangan yang memberikan definisi yang sama dengan Fatwa DSN-MUI No. 67 Tahun 2008 mengenai anjak piutang yang disebutkan dalam Pasal 1 ayat 1 yang berbunyi: "Anjak Piutang (factoring) adalah kegiatan pengalihan piutang dagang jangka pendek suatu perusahaan berikut pengurusan atas piutang tersebut sesuai dengan prinsip syariah". ${ }^{22}$

Perjanjian anjak piutang ini memberikan hak dan kewajiban bak bagi pihak klien, perusahaan factoring maupun costumer. Hak dan kewajiban tersebut telah diatur dalam Peraturan Badan Pengawas Pasar Modal dan Lembaga Keuangan. Adapun penjelasan mengenai hak dan kewajiban masing-masing pihak adalah sebagai berikut: Pertama, Hak dan kewajiban perusahaan pembiayaan (wakil) antara lain: ${ }^{23}$ 1) Menagih piutang pengalih piutang (muwakkil) kepada pihak yang berutang (muwakkil'alaih); 2) Dapat memperoleh upah (ujrah) atas jasa penagihan piutang pengalih piutang (muwakkil) dalam hal dapat dijanjikan; 3) Meminta jaminan dari pengalih piutang (muwakkil) (with recourse) atau tidak meminta jaminan dari pengalih piutang (muwakkil) (without recourse); dan 4) Membayar atau melunasi hutang pihak yang berhutang (muwakkal 'alaih) kepada pengalih piutang (muwakkil);

Kedua, Hak dan Kewajiban Pengalih Piutang (Muwakkil) antara lain: ${ }^{24}$ 1) Memperoleh pelunasan piutang dari Perusahaan Pembiayaan selaku wakil; 2) Membayar upah (ujrah) atas jasa pemindahan piutang sesuai yang diperjanjikan; 3) Dapat menyediakan jaminan kepada Perusahaan Pembiayaan selaku wakil dalam hal diperjanjikan, dan 4) Memberitahukan kepada pihak yang berhutang (muwakkil 'alaih) mengenai transaksi pemindahan piutang kepada Perusahaan Pembiayaan selaku wakil. Ketiga, Hak dan Kewajiban Pihak yang Berhutang (muwakkal alaih) antara lain: ${ }^{25}$ 1) Memperoleh informasi yang jelas mengenai transaksi pemindahan hutangnya dari pengalih piutang (muwakkil) kepada Perusahaan Pembiayaan selaku wakil, dan 2) Membayar atau melunasi hutang kepada Perusahaan Pembiayaan selaku wakil. Piutang (muwakkil bih) yang menjadi obyek wakâlah bil ujrah adalah piutang jangka pendek yang jatuh temponya kurang dari 1 (satu) tahun yang memenuhi ketentuan sebagai berikut: ${ }^{26}$ a) Piutang pengalih piutang (muwakkil) yang dipindahkan kepada Perusahaan Pembiayaan selaku wakil harus dipastikan oleh para pihak belum jatuh tempo dan tidak dalam kategori macet. b) Piutang yang dialihkan bukan berasal dari transaksi yang diharamkan oleh syariah Islam. c) Piutang pengalih piutang (muwakkil) harus dibuktikan dengan dokumen tagihan dan dipastikan keasliannya oleh para pihak.

21 Fathurrahman Djamil, Penerapan Hukum Perjanjian Dalam Transaksi Di Lembaga Keuangan Syariah (Jakarta: Sinar Grafika, 2013), 192.

${ }^{22}$ Pasal 1 ayat 1, Salinan Peraturan Ketua Badan Pengawas Pasar Modal Dan Lembaga Keuangan Nomor. Per.03/BL/2007 Tentang Kegiatan Perusahaan Pembiayaan Berdasarkan Prinsip Syariah

${ }^{23}$ Pasal 17 Salinan Peraturan Ketua Bapepam dan LK No. PER-04/BL/2007 tentang Akad-akad yang digunakan dalam Kegiatan Perusahaan Pembiayaan Berdasarkan Prinsip Syariah

${ }^{24}$ Pasal 18 Salinan Peraturan Ketua Bapepam dan LK No. PER-04/BL/2007 tentang Akad-akad yang digunakan dalam Kegiatan Perusahaan Pembiayaan Berdasarkan Prinsip Syariah

${ }^{25}$ Pasal 19 Salinan Peraturan Ketua Bapepam dan LK No. PER-04/BL/2007 tentang Akad-akad yang digunakan dalam Kegiatan Perusahaan Pembiayaan Berdasarkan Prinsip Syariah

${ }^{26}$ Pasal 20 Salinan Peraturan Ketua Bapepam dan LK No. PER-04/BL/2007 tentang Akad-akad yang digunakan dalam Kegiatan Perusahaan Pembiayaan Berdasarkan Prinsip Syariah

Jurisdictie: Jurnal Hukum dan Syariah Vol. 6 No. 2 Desember 2015 


\section{Konsep Akad Hiwâlah dalam Surat Edaran Bank Indonesia}

Akad hiwâlah merupakan salah satu produk pelayanan jasa perbankan syariah dalam hal pengalihan utang dari pihak yang berhutang. yang bertujuan memberikan kemudahan bagi seseorang yang tidak mampu membayar hutangnya, sehingga dapat dialihkan kepada pihak lain ataupun kepada suatu lembaga seperti lembaga perbankan syariah. Akad hiwâlah diatur dalam Undang-Undang Nomor 21 Tahun 2008 tentang Perbankan Syariah memberikan arti bahwa: "Yang dimaksud dengan akad hiwâlah adalah akad pengalihan utang dari pihak yang berutang kepada pihak lain yang wajib menanggung atau membayar." ${ }^{27}$ Adapun setiap produk bank syariah, termasuk produk pelayanan jasa perbankan syariah tidak terlepas dari Dewan Syariah Nasional Majelis Ulama Indonesia (DSN-MUI) yang mengeluarkan fatwa terkait produk dalam perbankan syariah, agar suatu produk yang dikeluarkannya berlandaskan prinsip syariah, salah satunya produk pelayanan jasa perbankan syariah dengan akad hiwâlah. Dikeluarkannya produk pelayanan jasa dengan akad hiwâlah didasarkan pada pertimbangan bahwa terkadang seseorang tidak mampu untuk membayar hutang kepada orang lain secara tunai, oleh karena itu, agar pihak yang memberi hutang tidak merasa dirugikan, maka pihak yang berhutang mengalihkan hutangnya kepada pihak lain atau kepada bank syariah. Atas dasar itulah, maka DSN-MUI mengeluarkan fatwa terkait dengan akad hiwâlah yaitu Fatwa DSN-MUI Nomor 12/DSN-MUI/IV/2000 tentang Hawâlah. Landasan hukum yang menjadi dasar dikeluarkannya fatwa hiwâlah yaitu pada hadis riwayat Bukhari dari Abu Hurairah yang berbunyi: "Menunda pembayaran bagi yang mampu adalah kezaliman. Dan jika seorang dari kamu diikutkan (dihawalahkan) kepada orang yang mampu, terimalah hawâlah itu. ${ }^{28}$

Hadis ini merujuk pada keabsahan akad hiwâlah. Pada hadis tersebut, Rasulullah memberitahukan kepada orang yang mengutangkan, jika orang yang berutang meng hiwâlahkan kepada orang yang kaya/mampu, hendaklah ia menerima hiwâlah tersebut dan hendaklah ia menagih kepada orang yang berutang (muhâl ) sehingga haknya dapat terpenuhi. Jumhur ulama berpendapat bahwa perintah untuk menerima hiwâlah dalam hadis tersebut menunjukan sunnah dan tidak wajib untuk menerima hiwâlah tersebut. Imam Daud dan Ahmad berpendapat bahwa perintah dalam hadis itu menunjukan wajib, jadi wajib untuk menerima hiwâlah tersebut. Hadis ini menunjukan bahwa akad hiwâlah adalah sah dan diperbolehkan oleh syariah. ${ }^{29}$ Penjelasan hadis di atas, menunjukan bahwa produk pelayanan jasa dengan akad hiwâlah dalam perbankan syariah diperbolehkan sesuai prinsip syariah, yang mana nasabah akan mengalihkan hutangnya kepada bank syariah, dan bank syariah harus menerima pengalihan hutang tersebut untuk menanggung atau membayarkan hutang tersebut kepada pihak lain. Setiap produk perbankan syariah tidak hanya diatur melalui beberapa fatwa DSN-MUI, namun Bank Indonesia juga mengatur terkait dengan pelaksanaan kegiatan operasional perbankan syariah baik yang berhubungan dengan penghimpunan dana, dan penyaluran dana, serta pelayanan jasa perbankan syariah yaitu dengan dikeluarkannya. Adanya peraturan Bank Indonesia terhadap produk-produk perbankan syariah, karena Bank Indonesia merupakan bank sentral yang memiliki tugas untuk menetapkan dan melaksanakan kebijakan moneter, mengatur dan menjaga kelancaran sistem pembayaran, serta mengatur dan mengawasi perbankan di Indonesia. ${ }^{30}$

Namun, setelah dikeluarkannya UU No. 21 tahun 2011 tentang Otoritas Jasa Keuangan, tugas bank Indonesia dalam hal pengaturan dan pengawasan perbankan di Indonesia beralih ke lembaga Otoritas Jasa Keuangan, karena pengaturan dan pengawasan tersebut sudah

\footnotetext{
${ }^{27}$ Penjelasan Pasal 19 ayat (1) huruf g Undang-Undang Nomor 21 Tahun 2008 tentang Perbankan Syariah

${ }^{28}$ Muhammad bin Ismail bin Ibrahim bin Mughirah al Bukhary, Shahih Al Bukhary (Beirut: Dar al-Fikr, 2006), 118.

${ }^{29}$ Rachmadi Usman, Produk Dan Akad Perbankan Syariah Di Indonesia, Implementasi Dan Aspek Hukum (Bandung: Citra Aditya Bakti, 2009), 280.

30 "Bank Indonesia," accessed April 19, 2015, http://id.m.wikipedia.org/wiki/Bank_Indonesia.

Jurisdictie: Jurnal Hukum dan Syariah Vol. 6 No. 2 Desember 2015
} 
menjadi kewenangan dari otoritas jasa keuangan. Sebagaimana dalam UU No. 21 tahun 2011 tentang Otoritas Jasa Keuangan bahwa yang dimaksud dengan Otoritas Jasa Keuangan, yang selanjutnya disingkat OJK, adalah lembaga yang independen dan bebas dari campur tangan pihak lain, yang mempunyai fungsi, tugas, dan wewenang, sebagaimana dimaksud dalam Undang-Undang ini. ${ }^{31}$ Otoritas Jasa Keuangan adalah lembaga negara yang dibentuk berdasarkan UU nomor 21 tahun 2011 yang berfungsi menyelenggarakan sistem pengaturan dan pengawasan yang terintegrasi terhadap keseluruhan kegiatan di dalam sektor jasa keuangan. Otoritas Jasa Keuangan, yang selanjutnya disingkat OJK, adalah lembaga yang independen dan bebas dari campur tangan pihak lain, yang mempunyai fungsi, tugas, dan wewenang pengaturan, pengawasan, pemeriksaan, dan penyidikan. OJK didirikan untuk menggantikan peran Bapepam-LK dalam pengaturan dan pengawasan pasar modal dan lembaga keuangan, dan menggantikan peran Bank Indonesia dalam pengaturan dan pengawasan bank, serta untuk melindungi konsumen industri jasa keuangan. ${ }^{32}$ Walaupun pengaturan dan pengawasan tersebut sudah menjadi kewenangan OJK, tetapi, dalam hal pengaturan produk suatu perbankan masih tetap menjadi tugas Bank Indonesia, misalnya, pengaturan produk-produk dalam perbankan syariah, terhadap produk pelayanan jasa dengan akad hiwâlah dalam perbankan syariah yang diatur dalam peraturan bank Indonesia, dimana peraturan tersebut menyerap peraturan atau pedoman dari Fatwa DSN-MUI.

Fatwa MUI sebagai pedoman bagi operasional perbankan syariah pada tahun 2005 sebagian besar dijadikan substansi dalam Peraturan Bank Indonesia (PBI). Hal ini terlihat dalam PBI No. 7/46/PBI/2005 tentang Akad Penghimpunan dan Penyaluran Dana Bagi Bank yang Melaksanakan Kegiatan Usaha Berdasarkan Prinsip Syariah. Adapun tujuan dikeluarkannya PBI ini adalah untuk mewujudkan kesamaan cara pandang pelaku industri perbankan syariah, termasuk pengelola bank/pemilik dana/pengguna dana, serta otoritas pengawas terhadap akad-akad produk penghimpunan dana dan penyaluran dana bank syariah. ${ }^{33}$ Dalam perkembangannya PBI No. 7/46/PBI/2005 dicabut dengan PBI No. 9/19/PBI/2007 tentang Pelaksanaan Prinsip Syariah dalam Kegiatan Penghimpunan Dana Dan Penyaluran Dana Serta Pelayanan Jasa Bank Syariah. Materi muatan fatwa tidak lagi terdapat dalam PBI No. 9/19/PBI/2007, namun dimasukkan dalam Surat Edaran Bank Indonesia (SEBI) No. 10/14/DPbs Jakarta 17 Maret 2008 Perihal Pelaksanaan Prinsip Syariah dalam Kegiatan Penghimpunan Dana dan Penyaluran Dana serta Pelayanan Jasa Bank Syariah. ${ }^{34}$ Adapun terkait dengan akad hiwâlah sebagai produk pelayanan jasa perbankan syariah, dalam Peraturan Bank Indonesia Nomor 9/19/PBI/2007 menjelaskan bahwa "hiwâlah adalah transaksi pengalihan utang dari satu pihak yang berutang kepada pihak lain yang wajib menanggung atau membayar". ${ }^{35}$ PBI No.9/19/PBI/2007 merupakan PBI yang hanya menjelaskan hal-hal umum yang berkaitan dengan pelaksanaan prinsip syariah baik pada karakteristik produk maupun operasional bank syariah, sedangkan teknis pelaksanaannya diatur dalam Surat Edaran Bank Indonesia No.10/14/DPbS.

Teknis pelaksanaan akad hiwâlah yang diatur dalam Surat Edaran Bank Indonesia No.10/14/DPbS menjelaskan teknis pengalihan utang atas dasar hiwâlah muthlaqah dan hiwâlah muqayyadah yang keduanya merupakan bentuk dari akad hiwâlah. Pelaksanaan hiwâlah muthlaqah yang diatur dalam Surat Edaran Bank Indonesia No.10/14/DPbS berlaku

\footnotetext{
${ }^{31}$ Pasal 1 ayat 1 Undang-Undang Nomor. 21 Tahun 2011 tentang Otoritas Jasa Keuangan

32 “Otoritas Jasa Keuangan,” accessed April 19, 2015, http://id.m.wikipedia.org/wiki/Otoritas_Jasa_Keuangan.

${ }^{33}$ Lihat Butir b PBI No. 7/46/PBI/2005 tentang Akad Penghimpunan dan Penyaluran Dana Bagi Bank yang Melaksanakan Kegiatan Usaha Berdasarkan Prinsip Syariah (Lembaran Negara Republik Indonesia Tahun 2005 Nomor 124, Tambahan Lembaran Negara Nomor 4563)

${ }^{34}$ Khotibul Umam, "Legislasi Fiqh Ekonomi Perbankan: Sinkronisasi Peran Dewan Syariah Nasional Dan Komite Perbankan Syariah," Mimbar Hukum 24, no. 2 (June 2012): 369.

35 Pasal 3 Peraturan Bank Indonesia Nomor 9/19/PBI/2007 Tentang Pelaksanaan Prinsip Syariah Dalam Kegiatan Penghimpunan Dana Dan Penyaluran Dana Serta Pelayanan Jasa Bank Syariah
}

Jurisdictie: Jurnal Hukum dan Syariah Vol. 6 No. 2 Desember 2015 
persyaratan sebagai berikut: a. Bank bertindak sebagai pihak yang menerima pengalihan utang atas utang nasabah kepada pihak ketiga. b. Bank wajib menjelaskan kepada nasabah mengenai karakteristik pemberian jasa pengalihan utang atas dasar akad hiwâlah, serta hak dan kewajiban nasabah sebagaimana diatur dalam ketentuan Bank Indonesia mengenai transparansi informasi produk bank dan penggunaan data pribadi nasabah. c. Bank wajib melakukan analisis atas rencana pemberian jasa pengalihan utang atas dasar akad hiwâlah bagi nasabah yang antara lain meliputi aspek personal berupa analisis karakter (character) dan/atau aspek usaha antara lain meliputi analisis kapasitas usaha (capacity), keuangan (capital), dan prospek usaha (condition). d. Bank dan nasabah wajib menuangkan kesepakatan dalam bentuk perjanjian tertulis berupa akad pengalihan utang atas dasar hiwâlah. e. Nilai pengalihan utang harus sebesar nilai nominal. f. Bank menyediakan dana talangan ( $q a r d h$ ) sebesar nilai pengalihan utang nasabah kepada pihak ketiga. g. Bank dapat meminta imbalan (ujrah) atau fee batas kewajaran pada nasabah, dan h. Bank dapat mengenakan biaya administrasi dalam batas kewajaran kepada nasabah.

Sedangkan pelaksanaan hiwâlah muqayyadah dalam Surat Edaran Bank Indonesia Nomor 10/14/Dpbs berlaku persyaratan sebagai berikut: a. Ketentuan kegiatan penyaluran dana dalam bentuk pemberian jasa pengalihan utang atas dasar akad hiwâlah muthlaqah sebagaimana dimaksud di atas, kecuali huruf a, huruf $f$, dan huruf g. b. Bank bertindak sebagai pihak yang menerima pengalihan utang atas utang nasabah kepada pihak ketiga, di mana sebelumnya bank memiliki utang kepada nasabah, dan c. Jumlah utang nasabah kepada pihak ketiga yang bisa diambil alih oleh bank, paling besar sebanyak nilai utang bank kepada nasabah. ${ }^{36}$ Akan tetapi, pelaksanaan akad hiwâlah dalam praktik perbankan syariah yaitu menggunakan akad hiwâlah muqayyadah karena memiliki hubungan yang saling terikat dan memiliki kejelasan risiko. Sedangkan dalam hiwâlah muthlaqah sangat rentan sekali akan risiko yang ditimbulkan dari pihak yang berutang (muhîl) karena adanya wanprestasi.

\section{Persamaan antara konsep anjak piutang syariah dalam Fatwa DSN-MUI dengan konsep akad hiwâlah dalam Surat Edaran Bank Indonesia}

Konsep anjak piutang syariah dengan konsep akad hiwâlah merupakan pengalihan utang piutang, yang mana, keduanya untuk memberikan kemudahan dari adanya transaksi utang piutang yang terkadang seseorang tidak mampu membayarnya secara langsung kepada pihak yang memberikan pinjaman. Oleh sebab itu, ia memindakan hutangnya kepada pihak lain untuk menanggung atau membayarnya. Definisi anjak piutang secara syariah yaitu pengalihan penyelesaian piutang atau tagihan jangka pendek dari pihak yang berpiutang kepada pihak lain yang kemudian menagih piutang tersebut kepada pihak yang berutang atau pihak yang ditunjuk oleh pihak yang berutang sesuai prinsip syariah. ${ }^{37}$ Sedangkan definisi akad hiwâlah yaitu akad pengalihan utang dari satu pihak yang berutang kepada pihak lain yang wajib menanggung atau membayarnya. ${ }^{38}$ Dari definisi di atas, konsep anjak piutang syariah dengan konsep akad hiwâlah memiliki persamaan yakni sebagai konsep pengalihan. Konsep pengalihan tersebut atas utang piutang sebagai solusi bagi pihak debitur atau pihak yang berhutang untuk mengalihkan kepada lembaga anjak piutang atau lembaga perbankan yang memberikan jasa pengalihan utang dengan akad hiwâlah. Jika ditinjau dari segi obyek terdiri dari dua jenis yaitu hiwâlah dayn dan hiwâlah haqq. Hiwâlah dayn adalah pemindahan hutang atau kewajiban membayar/melunasi utang yang dimiliki seseorang atau satu pihak kepada orang atau pihak lain. Sedangkan hiwâlah haqq adalah pemindahan hak atau piutang atau tagihan yang dimiliki seseorang atau satu pihak kepada orang atau pihak lain. ${ }^{39}$

\footnotetext{
${ }^{36}$ Usman, Produk Dan Akad Perbankan Syariah Di Indonesia, 283-285.

${ }^{37}$ Fatwa DSN-MUI No. 67/DSN-MUI/III/2008 tentang Anjak Piutang Syariah

${ }^{38}$ Fatwa DSN-MUI No. 12/DSN-MUI/IV/2000 tentang Hawalah

${ }^{39}$ Djamil, Penerapan Hukum Perjanjian, 207.

Jurisdictie: Jurnal Hukum dan Syariah Vol. 6 No. 2 Desember 2015
} 
Hiwâlah dayn dan hiwâlah haqq sesungguhnya sama saja, tergantung dari sisi mana melihatnya. Disebut hiwâlah dayn jika kita memandangnya sebagai pengalihan utang, sedangkan sebutan hiwâlah haqq jika kita memandangnya sebagai pengalihan piutang. Berdasarkan definisi ini, maka anjak piutang syariah termasuk ke dalam kelompok hiwâlah haqq karena adanya kesamaan obyek yaitu berupa piutang. Selain itu, konsep anjak piutang juga memiliki kesamaan dengan jenis akad hiwâlah dari jenis lain yaitu hiwâlah muthlaqah. Hiwâlah ini di mana muhîl adalah orang yang berutang tetapi tidak berpiutang kepada muhâl 'alaih. ${ }^{40}$ Sebagaimana dalam anjak piutang syariah, pihak wakil sebelumnya tidak memiliki hutang kepada pihak yang berutang (muwakkal 'alaih), dan pihak pengalih piutang hanya mengalihkan piutang tersebut kepada perusahaan factor (sebagai wakil) untuk membayar hutang pihak nasabah kepada klien, sehingga perusahaan factor hanya bersifat mewakilkan untuk membayar sejumlah hutang nasabah kepada pihak klien tanpa mempunyai hutang kepada nasabah. Dengan demikian, pihak perusahaan factor atau wakil tidak memiliki hutang terlebih dahulu kepada pihak nasabah, sehingga hal ini dikatakan sama dengan hiwâlah muthlaqah sebagai pemindahan hutang yang tidak ditegaskan sebagai ganti rugi dari pembayaran hutang pihak pertama kepada pihak kedua. Ini terjadi jika seseorang memindahkan hutangnya agar ditanggung muhâl 'alaih, sedangkan ia tidak mengaitkannya dengan utang piutang mereka, sementara muhâl 'alaih menerima hiwâlah tersebut.

Selain itu, pengaturan konsep anjak piutang syariah dalam Fatwa DSN-MUI juga memiliki titik kesamaan dengan konsep hiwâlah muthlaqah dalam Surat Edaran Bank Indonesia. Titik persamaan tersebut bahwa keduanya dapat memberikan dana talangan (qardh) dan dapat mengambil ujrah atau fee. Sebagaimana disebutkan dalam ketentuan akad anjak piutang syariah dalam Fatwa DSN-MUI yang terdapat pada point (d) menyebutkan bahwa "pihak yang ditunjuk menjadi wakil dapat memberikan dana talangan (qardh) kepada pihak yang berpiutang sebesar nilai piutang," dan dalam point (e) menyebutkan bahwa "atas jasanya untuk melakukan penagihan tersebut, pihak yang ditunjuk menjadi wakil dapat memperoleh ujrah/fee." Dalam akad hiwâlah muthlaqah juga menyebutkan salah satu persyaratan dalam point (f) bahwa "bank menyediakan dana talangan (qardh) sebesar nilai pengalihan utang nasabah kepada pihak ketiga, dan point (g) bahwa bank dapat meminta imbalan (ujrah) atau fee batas kewajaran pada nasabah. Dengan demikian, anjak piutang syariah maupun hiwâlah muthlaqah berhak mendapatkan ujrah/fee atas jasanya, walaupun dalam hal ini, anjak piutang syariah mendapatkan ujrah/fee tersebut didasarkan atas jasanya dalam menagih utang kepada pihak yang berutang. Sedangkan hiwâlah muthlaqah ujrah/fee tersebut didasarkan atas jasanya yang menerima pengalihan utang tersebut untuk membayarkan hutangnya muhîl. Untuk kasus anjak piutang, bank dapat memberikan fasilitas pengambilalihah piutang, yaitu yang disebut hiwâlah. Tetapi untuk fasilitas ini pun bank tidak dibenarkan meminta imbalan kecuali biaya layanan atau biaya administrasi dan biaya penagihan. Dengan demikian, bank syariah meminjamkan uang (qardh) sebesar piutang yang tertera dalam dokumen piutang (wesel tagih atau promes) yang diserahkan kepada bank tanpa potongan. Hal itu adalah bila ternyata pada saat jatuh tempo hasil tagihan itu digunakan untuk melunasi hutang nasabah kepada bank. Tetapi bila ternyata piutang tersebut tidak ditagih, maka nasabah harus membayar kembali hutangnya itu kepada bank. Selain itu, sebagian ulama memberikan jalan keluar berupa pembelian surat hutang (bai'al dayn), tetapi sebagian ulama melarangnya. ${ }^{41}$

Baik anjak piutang syariah maupun akad hiwâlah dapat memberikan atau meminjamkan uang berupa dana talangan (qardh) untuk membayarkan piutangnya tersebut sesuai dengan jumlah piutangnya dan bank berhak mendapatkan ujrah/fee atas jasa pemindahan piutang

\footnotetext{
${ }^{40}$ Fatwa DSN-MUI No. 58/DSN-MUI/V/2007 tentang Hawalah bil Ujrah

41"Mengenal Lembaga Pembiayaan http://alimuhayatsyahbloger.blogspot.com/2011/01/mengenal-lembaga pembiayaan-syariah.html,. Jurisdictie: Jurnal Hukum dan Syariah Vol. 6 No. 2 Desember 2015
} 
tersebut. Mengenai proses pengalihan piutang dalam transaksi anjak piutang syariah, memiliki persamaan dengan istilah cessie yang diatur dalam KUH Perdata. Istilah cessie adalah cara pengalihan dan/atau penyerahan piutang atas nama sebagaimana yang dimaksud di dalam Pasal 613 Kitab Undang-Undang Hukum Perdata (KUH Perdata). Adapun Pasal 613 KUH Perdata berbunyi: "Penyerahan akan piutang-piutang atas nama dan kebendaan tak bertubuh lainnya, dilakukan dengan jalan membuat sebuah akta autentik atau di bawah tangan, dengan mana hak-hak atas kebendaan itu dilimpahkan kepada orang lain. penyerahan yang demikian bagi si berutang tiada akibatnya, melainkan setelah penyerahan itu diberitahukan kepadanya, atau secara tertulis disetujui dan diakuinya. Penyerahan tiap-tiap piutang karena surat bawa dilakukan dengan penyerahan surat itu, penyerahan tiap-tiap piutang karena surat tunjuk dilakukan dengan penyerahan surat disertai dengan endorsemen" 42 Apabila memperhatikan ketentuan Pasal 613 KUH Perdata, pengaturan di dalam Pasal 613 KUH Perdata adalah mengenai penyerahan piutang atas nama dan kebendaan tidak bertubuh lainnya. Sehubungan dengan kata "piutang" di dalam Pasal 613 KUH Perdata, hal ini menunjukkan bahwa yang dapat dialihkan adalah suatu piutang dan bukanlah suatu hutang. Sehubungan dengan itu, maka hanya kreditur yang dapat melakukan pengalihan atas piutangnya sedangkan debitur tidak berhak untuk melakukan pengalihan atas hutangnya. ${ }^{43}$

Penerapan ketentuan dalam Pasal 613 tersebut terhadap suatu transaksi factoring menimbulkan konsekuensi antara lain bahwa setiap transaksi factoring haruslah diikuti dengan penyerahan hak lewat suatu akta khusus (outentik atau akta dibawah tangan), yakni yang disebut dengan "akta cessie" dan adanya salah satu di antara hal berikut, yaitu adanya notifikasi oleh kreditur lama kepada debitur, atau persetujuan tertulis ataupun pengakuan dari debitur tentang adanya pengalihan piutang. ${ }^{44}$ Dalam konsep hukum perdata, hiwâlah serupa dengan lembaga pengambilalihan hutang (schuldoverneming), atau lembaga pelepasan hutang atau penjualan utang (debt sale), atau lembaga penggantian kreditur atau penggantian debitur. Dalam hukum perdata, dikenal lembaga yang disebut subrogasi atau novasi, yaitu lembaga hukum yang memungkinkan terjadinya penggantian kreditur atau debitur. Menurut penulis, konsep hiwâlah lebih mirip dengan subrogasi, karena konsep hiwâlah sebagai penggantian kreditur, dikatakan sebagai penggantian kreditur karena pihak nasabah (muhîl) memindahkan atau mengalihkan hutangnya kepada bank syariah (muhâl 'alaih), yang mana bank syariah berkedudukan sebagai kreditur baru menggantikan nasabah lain (muhâl) yang memberikan pinjaman kepada nasabah pertama (muhîl). Sesuai dengan Pasal 1400 KUHPerdata, subrogasi adalah suatu pergantian hak-hak dari kreditur oleh seorang pihak ketiga, yang membayar kepada si berpiutang itu, terjadi baik dengan persetujuan maupun demi undangundang. ${ }^{45}$

Dengan adanya subrogasi, salah satu akibat hukum yang penting adalah bahwa kreditur baru menempati kedudukan kreditur lama, sehingga pihak kreditur baru dapat menagih langsung piutangnya dari pihak debitur. Maka dari itu, pergantian yang ada pada akad hiwâlah sama dengan pergantian yang ada pada subrogasi yaitu pihak bank yang menanggung atau membayar utang berkedudukan sebagai kreditur baru menggantikan kedudukan kreditur lama atau nasabah lain yang memberikan pinjaman utang kepada debitur.

\footnotetext{
42 Pasal 613 Kitab Undang-Undang Hukum Perdata (Burgelijk Wetboek)

${ }^{43}$ Pengalihan Piutang, http://131027-T\%2027405-Pengalihan\%20piutang-Analisis_2, 1 Maret 2015

${ }^{44}$ Munir Fuady, Hukum Tentang Pembiayaan Dalam Teori Dan Praktek (Leasing, Factoring, Modal Ventura, Pembiayaan Konsumen, Kartu Kredit) (Bandung: Citra Aditya Bakti, 1995), 91.

${ }^{45}$ Pasal 1400 Kitab Undang-Undang Hukum Perdata (Burgelijk Wetboek)

Jurisdictie: Jurnal Hukum dan Syariah Vol. 6 No. 2 Desember 2015
} 
Tabel 1. Persamaan Anjak Piutang Syariah dengan Akad Hiwâlah

\begin{tabular}{|c|c|c|c|}
\hline No & Unsur Persamaan & Anjak Piutang & Akad Hiwâlah \\
\hline 1 & Definisi & Konsep Pengalahan & Konsep Pengalahan \\
\hline 2 & Obyek & Piutang & Piutang \\
\hline 3 & Jenis lain & Para pihak tidak terikat & Hiwâlah muthlaqah \\
\hline 4 & Bentuk akad & $\begin{array}{l}\text { Dalam Fatwa DSN MUI } \\
\text { terdapat dalam point d } \\
\text { "Pihak yang ditunjuk } \\
\text { menjadi wakil dapat } \\
\text { memberikan dana talangan } \\
\text { (qardh) kepada pihak yang } \\
\text { berpiutang sebesar nilai } \\
\text { piutang". Pada point e } \\
\text { "Atas jasanya melakukan } \\
\text { penagihan tersebut, pihak } \\
\text { yang ditunjuk menjadi } \\
\text { wakil dapat memperoleh } \\
\text { ujrah/fee. }\end{array}$ & $\begin{array}{lr}\text { Dalam SEBI syarat } \\
\text { hiwâlah muthlaqah } \\
\text { terdapat dalam point } \\
\text { f } & \text { "Bank } \\
\text { menyediakan dana } \\
\text { talangan (qardh) } \\
\text { sebesar nilai } \\
\text { pengalihan utang } \\
\text { nasabah kepada } \\
\text { pihak ketiga". pada } \\
\text { point g "Bank dapat } \\
\text { meminta imbalan } \\
\text { (ujrah) atau fee batas } \\
\text { kewajaran pada } \\
\text { nasabah". }\end{array}$ \\
\hline 5 & $\begin{array}{l}\text { Dalam KUHPerdata } \\
\text { kaitannya dengan } \\
\text { cessie dan subrogasi }\end{array}$ & $\begin{array}{l}\text { Sebagai bentuk pengalihan } \\
\text { dan/atau penyerahan } \\
\text { piutang atas nama }\end{array}$ & $\begin{array}{l}\text { Penggantian kreditur } \\
\text { lama kepada kreditur } \\
\text { baru }\end{array}$ \\
\hline
\end{tabular}

\section{Perbedaan antara konsep anjak piutang syariah dalam Fatwa DSN-MUI dengan konsep akad hiwâlah dalam Surat Edaran Bank Indonesia}

Konsep anjak piutang syariah dengan akad hiwâlah dibandingkan dalam skripsi ini untuk menemukan perbedaan antara anjak piutang syariah dengan akad hiwâlah yang memiliki konsep dasar yang sama yaitu konsep pengalihan, sebagaimana yang telah dijelaskan di atas. Dalam Pasal 1 ayat 1 yang berbunyi: "Anjak Piutang (factoring) adalah kegiatan pengalihan piutang dagang jangka pendek suatu perusahaan berikut pengurusan atas piutang tersebut sesuai dengan Prinsip Syariah."46 Sedangkan yang dimaksud dengan akad hiwâlah adalah akad pengalihan utang dari pihak yang berutang kepada pihak lain yang wajib menanggung atau membayar." ${ }^{47}$ Melihat definisi di atas, selain memiliki persamaan, juga memiliki perbedaan yang terlihat sangat jelas, bahwa anjak piutang syariah berupa pengalihan piutang beserta pengurusan piutang. Dengan demikian transaksi tersebut menggunakan akad wakâlah bil ujrah. Akad wakâlah bil ujrah bisa dilaksanakan dengan atau tanpa upah. Ketika akad wakâlah telah sempurna maka akad tersebut bersifat mengikat. Dalam artian wakil dihukumi layaknya ajir (orang yang disewa tenaganya) yang memiliki kewajiban untuk menyelesaikan sebuah pekerjaan, kecuali ada halangan yang bersifat syar'i. Jika dalam akad wakâlah tersebut upah tidak disebutkan secara jelas, maka wakil berhak atas ujrah mitsil

46 Pasal 1 ayat 1, Salinan Peraturan Ketua Badan Pengawas Pasar Modal Dan Lembaga Keuangan Nomor. Per.03/BL/2007 Tentang Kegiatan Perusahaan Pembiayaan Berdasarkan Prinsip Syariah

${ }^{47}$ Penjelasan Pasal 19 ayat (1) huruf g Undang-Undang Nomor 21 Tahun 2008 tentang Perbankan Syariah Jurisdictie: Jurnal Hukum dan Syariah Vol. 6 No. 2 Desember 2015 
(upah sepadan), atau sesuai dengan adat kebiasaan yang berlaku. Jika memang dalam adat tersebut tidak berlaku pemberian upah, maka akad kembali menjadi akad aslinya yang bersifat tabarru' (charity program). Jika demikian halnya, akad tidak bersifat mengikat dan wakil memiliki hak untuk membatalkan kapan saja. Ini menurut pendapat Hanafiyah, Malikiyyah dan Hanabilah. Menurut Syafi'iyah, walaupun akad wakâlah dijalankan dengan adanya pemberian upah, akad tersebut tetap tidak bersifat mengikat. ${ }^{48}$

Namun dalam kegiatannya, transaksi anjak piutang menggunakan akad wakâlah bil ujrah karena pihak klien mengalihkan kepada perusahaan anjak piutang serta melakukan pengurusan piutang, sehingga dalam hal ini, pihak perusahaan factoring sebagai wakil dalam pengurusan piutang tersebut dan berhak mendapatkan ujrah atas pengurusan piutang. Dalam Keputusan Menteri Keuangan No. 172/KMK.06/2002 dijelaskan bahwa kegiatan usaha Anjak Piutang dilakukan dalam bentuk: 1. Pembelian atau penagihan 2. Pengurusan piutang atau tagihan 3. Perdagangan dalam atau luar negeri. ${ }^{49}$ Sedangkan akad hiwâlah hanya berupa pengalihan utang tanpa adanya pengurusan piutang. Perbedaan lain antara konsep anjak piutang syariah dengan konsep akad hiwâlah dilihat dari pihak yang mengalihkan (subyek). Jika dalam anjak piutang, pihak yang mengalihkan adalah dari pihak klien. Di karenakan berupa pengalihan piutang, maka yang mengalihkan piutang tersebut adalah dari pihak klien atau muwakkil sebagai pengalih piutang kepada perusahaan factoring. Sedangkan dalam akad hiwâlah pihak yang mengalihkan yaitu pihak muhîl atau orang yang berutang, karena memang pihak muhîl lah yang meminta kepada bank syariah atau muhâl 'alaih untuk menanggung atau membayar utang muhîl. Adapun terkait dengan lembaga baik yang bergerak di bidang perusahaan anjak piutang dan pengalihan utang berdasarkan akad hiwâlah. Perusahaan yang bergerak di bidang anjak piutang yakni sebagai pengalihan piutang adalah perusahaan pembiayaan. Sebagaimana disebutkan dalam Pasal 2 huruf b bahwa salah satu perusahaan pembiayaan melakukan kegiatan usaha anjak piutang. ${ }^{50}$

Selain itu, dalam Pasal 5 Peraturan Badan Pengawas Pasar Modal dan Lembaga Keuangan menyebutkan bahwa "Setiap Perusahaan Pembiayaan yang melakukan kegiatan usaha berdasarkan Prinsip Syariah wajib menyalurkan dana untuk kegiatan pembiayaan berdasarkan Prinsip Syariah." ${ }^{, 1}$ Dan dalam Pasal 6 huruf b Peraturan Badan Pengawas Pasar Modal dan Lembaga Keuangan salah satu Kegiatan pembiayaan berdasarkan Prinsip Syariah sebagaimana dimaksud dalam Pasal 5 adalah: Anjak Piutang, yang dilakukan berdasarkan akad Wakâlah bil Ujrah. ${ }^{52}$ Jadi, lembaga yang memiliki otoritas untuk menjalankan kegiatan anjak piutang yakni perusahaan pembiayaan yang khusus bergerak di bidang anjak piutang berupa badan usaha yang berbadan hukum, seperti Perseroan Terbatas. Berbeda dengan akad hiwâlah, akad hiwâlah merupakan salah satu produk jasa perbankan syariah yakni sebagai pengalihan utang. Dalam Pasal 19 huruf g Undang-Udang Perbankan Syariah disebutkan bahwa kegiatan usaha bank umum syariah meliputi melakukan pengambilalihan utang berdasarkan Akad hawalah atau Akad lain yang tidak bertentangan dengan Prinsip Syariah. ${ }^{53}$ Dengan demikian, sudah jelas bahwa akad hiwâlah menjadi salah satu kegiatan bank syariah. Selain menjadi bagian dari produk pelayanan jasa perbankan syariah, akad hiwâlah juga diaplikasikan kepada lembaga selain perbankan syariah yaitu lembaga keuangan syariah seperti Baitul Maal wa Tamwil (BMT).

\footnotetext{
${ }^{48}$ Dimyauddin Djuwaini, Pengantar Fiqh Muamalah (Yogyakarta: Pustaka Pelajar, 2008), 240-241.

49 Wiroso, Produk Perbankan Syariah, (Dilengkapi Dengan UU No. 21/2008-Perbankan Syariah Kodifikasi Produk Bank Indonesia (Jakarta: LPFE Usakti, 2009), 24.

${ }^{50}$ Pasal 2 huruf b Peraturan Menteri Keuangan Nomor. 84/PMK.012/2006 tentang Perusahaan Pembiayaan

51 Pasal 5 Salinan Peraturan Ketua Badan Pengawas Pasar Modal dan Lembaga Keuangan Nomor. PER03/BL/2007 tentang Kegiatan Perusahaan Pembiayaan Berdasarkan Prinsip Syariah

52 Pasal 6 huruf b Salinan Peraturan Ketua Badan Pengawas Pasar Modal dan Lembaga Keuangan Nomor. PER03/BL/2007 tentang Kegiatan Perusahaan Pembiayaan Berdasarkan Prinsip Syariah

${ }^{53}$ Pasal 19 huruf g Undang-Undang Nomor. 21 tahun 2008 tentang Perbankan Syariah

Jurisdictie: Jurnal Hukum dan Syariah Vol. 6 No. 2 Desember 2015
} 
Dilihat dari obyek yang menjadi transaksi antara anjak piutang syariah dengan akad hiwâlah, hal ini sangat berbeda. Apabila dalam anjak piutang, obyek yang dijadikan transaksi adalah piutang. Piutang yang merupakan objek bisnis factoring adalah apa yang disebut dengan piutang dagang. Yaitu tagihantagihan bisnis yang belum jatuh tempo (account receivable), baik yang dikeluarkan dengan memakai surat berharga, seperti promisorry notes, atau hanya berupa tagihan invoice dagang biasa. Jadi factoring bukan ditujukan terhadap piutang yang sudah macet. Adapun piutang dagang, yang seperti biasanya merupakan objek bisnis factoring, dapat disebutkan sebagai berikut: a. Piutang yang terdiri dari seluruh tagihan berdasarkan invoice-invoice dari suatu perusahaan yang belum jatuh tempo. b. Piutang yang timbul dari surat-surat berharga yang belum jatuh tempo. c. Piutang yang timbul dari suatu proses pengiriman barang, jadi sebagai pengganti LC. d. Piutang yang merupakan tagihantagihan tertentu yang belum jatuh tempo. Misalnya yang terbit dari penggunaan kartu kredit, biro perjalanan, dan sebagainya. ${ }^{54}$

Sedangkan obyek yang menjadi transaksi dalam akad hiwâlah yakni obyek utang (muhâl bih). Menurut mayoritas ulama, syarat muhâl bih ada dua, yaitu adanya utang muhâl 'alaih kepada muhîl. Kalau tidak ada utang maka akad yang dilakukan adalah sebagai wakâlah bukan sebagai hiwâlah, dan utang harus sesuatu yang lazim atau mengikat. Sementara itu, menurut ulama madzhab Hanafi, adanya utang muhâl 'alaih kepada muhîl sebelum akad tidak dianggap sebagai syarat sah hiwâlah. Menurutnya, hiwâlah dianggap sah, baik ada utang muhâl 'alaih kepada muhîl ataupun tidak, baik hiwâlah muthlaqah (umum) maupun hiwâlah muqayyadah (khusus). ${ }^{55}$ Sehingga obyek yang ada pada transaksi anjak piutang maupun akad hiwâlah adalah obyek yang bebeda, karena obyek yang ada pada anjak piutang syariah berupa obyek yang timbul dari transaksi perdagangan baik dilakukan di dalam negeri maupun luar negeri, sedangkan obyek dalam akad hiwâlah hanya berupa utang nasabah kepada pihak lain agar pihak bank membayarkan utangnya tersebut, baik sebelumnya bank mempunyai utang terlebih dahulu kepada nasabah ataupun tidak. Mekanisme anjak piutang memiliki perbedaan dengan jenis akad hiwâlah berupa hiwâlah muqayyadah. Dijelaskan bahwa dalam konsep anjak piutang syariah pihak wakil atau perusahaan factoring tidak memiliki hutang terlebih dahulu kepada pihak yang berhutang/muwakkal 'alaih.

Hal ini sangat berbeda dengan konsep hiwâlah muqayyadah di mana orang yang berutang mengalihkan utangnya kepada muhâl 'alaih dengan mengaitkannya pada utang muhâl 'alaih padanya (muhîl). Sehingga pihak bank sebelumnya memiliki hutang kepada nasabah. Oleh karena itu dalam praktik bisnis yang dilaksanakan adalah pemindahan hutang secara terikat atau hiwâlah muqayyadah (pemindahan hutang atas hutang yang dimiliki sebagai gantinya) karena kejelasannya dan risiko yang dapat dipagari. ${ }^{56}$ Sebagaimana salah satu persyaratan akad hiwâlah muqayyadah dalam Surat Edaran Bank Indonesia Nomor 10/14/Dpbs tanggal 17 Maret 2008 point b disebutkan bahwa Bank bertindak sebagai pihak yang menerima pengalihan utang atas utang nasabah kepada pihak ketiga, di mana sebelumnya bank memiliki utang kepada nasabah. Di samping itu, konsep anjak piutang syariah dalam Fatwa DSN-MUI membolehkan memberikan dana talangan (qardh) serta memperoleh ujrah/fee sebagaimana yang telah dijelaskan dalam ketentuan akad anjak piutang syariah yang diatur dalam Fatwa DSN-MUI, akan tetapi berbeda dengan konsep akad hiwâlah muqayyadah tidak mensyaratkan adanya dana talangan (qardh) serta memperoleh ujrah/fee karena di antara tiga pihak tersebut saling memiliki hubungan muamalat (utang piutang) melalui transaksi pengalihan utang. Hal lain yang menjadi aspek perbedaan antara anjak piutang syariah dalam Fatwa DSN-MUI dengan akad hiwâlah dalam Surat Edaran Bank

\footnotetext{
${ }^{54}$ Munir Fuady, Hukum Tentang Pembiayaan (Bandung: Citra Aditya Bakti, 2014), 72.

${ }^{55}$ Djamil, Penerapan Hukum Perjanjian, 207.

${ }^{56}$ Abdul Ghofur Anshori, Perbankan Syariah Di Indonesia (Yogyakarta: Gadjah Mada University Press, 2009), 156.
}

Jurisdictie: Jurnal Hukum dan Syariah Vol. 6 No. 2 Desember 2015 
Indonesia berkaitan dengan penyelesaian sengketa. Dalam Fatwa DSN-MUI tentang anjak piutang syariah disebutkan dalam ketentuan penutup Fatwa tersebut bahwa Jika salah satu pihak tidak menunaikan kewajibannya atau jika terjadi perselisihan di antara para pihak, maka penyelesaiannya dilakukan melalui Badan Arbitrase Syariah atau Pengadilan Agama setelah tidak tercapai kesepakatan melalui musyawarah. ${ }^{57}$

Berbeda dengan dalam Surat Edaran Bank Indonesia yang tidak menyebutkan secara tegas mengenai penyelesaian sengketa, karena Surat Edaran No. 10/14/DPbS ini adalah merupakan penjelasan dan panduan teknis dari PBI No. 9/19/PBI/2008 tanggal 17 Desember 2007 tentang Pelaksanaan Prinsip Syariah dalam Kegiatan Penghimpunan Dana dan Penyaluran Dana serta Pelayanan jasa Bank Syariah, dimana PBI ini merupakan penyempurnaan/perubahan dari PBI No. 7/46/PBI 2006 tanggal 14 November 2005 tentang Akad Penghimpunan dan Penyaluran Dana bagi Bank yang Melaksanakan Kegiatan Usaha Berdasarkan Prinsip Syariah. ${ }^{58}$ Dengan demikian, Surat Edaran Bank Indonesia hanya merupakan surat edaran yang menjelaskan secara teknis terkait dengan kegiatan akad hiwâlah, baik hiwâlah muthaqlah maupun hiwâlah muqayyadah.

Tabel 2. Perbedaan Anjak Piutang Syariah dengan Akad Hiwâlah

\begin{tabular}{|c|c|c|c|}
\hline No & Unsur Perbedaan & Anjak Piutang & Akad Hiwâlah \\
\hline 1 & Definisi & $\begin{array}{l}\text { Pengalihan piutang dan } \\
\text { pengurusan piutang }\end{array}$ & $\begin{array}{l}\text { Hanya pengalihan } \\
\text { utang }\end{array}$ \\
\hline 2 & $\begin{array}{l}\text { Pihak yang } \\
\text { mengalihkan (subyek) }\end{array}$ & Pihak klien (muwakkil) & $\begin{array}{l}\text { Pihak yang berutang } \\
\text { (muhîl) }\end{array}$ \\
\hline 3 & Lembaga & $\begin{array}{l}\text { Perusahaan pembiayaan } \\
\text { maupun bank syariah }\end{array}$ & Bank syariah \\
\hline 4 & Obyek transaksi & $\begin{array}{l}\text { Piutang dagang dari } \\
\text { transaksi perdagangan } \\
\text { dalam atau luar negeri }\end{array}$ & $\begin{array}{l}\text { Berupa utang nasabah } \\
\text { kepada pihak lain }\end{array}$ \\
\hline 5 & Pendanaan & $\begin{array}{l}\text { Adanya dana talangan } \\
\text { (qardh)dan memperoleh } \\
\text { ujrah/fee }\end{array}$ & $\begin{array}{lr}\text { Tidak ada } & \text { dana } \\
\text { talangan dan } & \text { ujrah/fee } \\
\text { dalam } & \text { hiwâlah } \\
\text { muqayyadah, terdapat } \\
\text { dalam point } \text { b dalam } \\
\text { SEBI }\end{array}$ \\
\hline 6 & Penyelesaian sengketa & $\begin{array}{l}\text { Dalam Fatwa DSN-MUI } \\
\text { disebutkan dengan jelas } \\
\text { penyelesaian sengketa } \\
\text { melalui Badan Arbitrase } \\
\text { Syariah atau Pengadilan } \\
\text { Agama }\end{array}$ & $\begin{array}{l}\text { Dalam SEBI tidak } \\
\text { menyebutkan } \\
\text { penyelesaian sengketa }\end{array}$ \\
\hline
\end{tabular}

${ }^{57}$ Ketentuan Penutup Fatwa DSN-MUI Nomor. 67/DSN-MUI/III/2008

${ }^{58}$ Surat Edaran Bank Indonesia Nomor 10/14/DPbS, 16 Maret 2015, http://www.ojk.go.id/surat-edaran-bankindonesia-nomor-10-14-dpbs,

Jurisdictie: Jurnal Hukum dan Syariah Vol. 6 No. 2 Desember 2015 


\section{Kesimpulan}

Berdasarkan uraian di atas dapat diambil kesimpulan: Pertama, Konsep anjak piutang menurut Fatwa DSN-MUI merupakan konsep anjak piutang yang berdasarkan prinsip syariah, yang bertujuan untuk menghindari dari praktik yang dilarang oleh hukum Islam seperti riba, gharar, dan maisir. Anjak piutang secara syariah yang diatur dalam Fatwa DSN-MUI No. 67 Tahun 2008 merupakan peraturan yang berdasarkan prinsip syariah dengan menggunakan akad wakâlah bil ujrah. Sedangkan konsep akad hiwâlah diatur dalam dalam Peraturan Bank Indonesia Nomor 9/19/PBI/2007 menjelaskan bahwa "hiwâlah adalah transaksi pengalihan utang dari satu pihak yang berutang kepada pihak lain yang wajib menanggung atau membayar. Adapun teknis pelaksanaannya diatur dalam Surat Edaran Bank Indonesia No.10/14/DPbS. Teknis pelaksanaan akad hiwâlah yang diatur dalam Surat Edaran Bank Indonesia No.10/14/DPbS menjelaskan teknis pengalihan utang atas dasar hiwâlah muthlaqah dan hiwâlah muqayyadah yang keduanya merupakan bentuk dari akad hiwâlah. Kedua, Anjak piutang syariah dalam fatwa DSN-MUI dengan akad hiwâlah dalam Surat Edaran Bank Indonesia memiliki beberapa persamaan antara lain dalam aspek definisi dan mekanisme. Sedangkan perbedaan di antara keduanya berkaitan dengan pengurusan piutang, pihak yang mengalihkan hutang, lembaga pelaksana, obyek transaksi, pemberian dana talangan ( $q a r d h)$ dan fee, dan lembaga penyelesaian sengketa.

\section{Daftar Pustaka}

Al Arif, M. Nur Rianto. Dasar-Dasar Pemasaran Bank Syariah. Jakarta: IBFIM, 2010.

Anshori, Abdul Ghofur. Perbankan Syariah Di Indonesia. Yogyakarta: Gadjah Mada University Press, 2009.

“Bank Indonesia.” Accessed April 19, 2015. http://id.m.wikipedia.org/wiki/Bank_Indonesia.

Bukhary, Muhammad bin Ismail bin Ibrahim bin Mughirah al. Shahih Al Bukhary. 5 vols. Beirut: Dar al-Fikr, 2006.

Burhanuddin S. Aspek hukum lembaga keuangan syariah. Yogyakarta: Graha Ilmu, 2010.

—. Hukum Kontrak Syariah. Yogyakarta: BPFE-Yogyakarta, 2009.

Djamil, Fathurrahman. Penerapan Hukum Perjanjian Dalam Transaksi Di Lembaga Keuangan Syariah. Jakarta: Sinar Grafika, 2013.

Djuwaini, Dimyauddin. Pengantar Fiqh Muamalah. Yogyakarta: Pustaka Pelajar, 2008.

Fuady, Munir. Hukum Tentang Pembiayaan. Bandung: Citra Aditya Bakti, 2014.

. Hukum Tentang Pembiayaan Dalam Teori Dan Praktek (Leasing, Factoring, Modal

Ventura, Pembiayaan Konsumen, Kartu Kredit). Bandung: Citra Aditya Bakti, 1995.

Ibrahim, Johnny. Teori Dan Metode Penelitian Hukum Normatif. Malang: Bayu Media

Publishing, 2006.

Kasmir. Bank \& Lembaga Keuangan Lainnya. Jakarta: RajaGrafindo Persada, 2005.

Marzuki, Peter Mahmud. Penelitian Hukum. Jakarta: Kencana, 2010.

"Mengenal Lembaga Pembiayaan Syariah," 2015.

http://alimuhayatsyahbloger.blogspot.com/2011/01/mengenal-lembaga pembiayaansyariah.html,.

Nasution, Bahder Johan. Metode Penelitian Ilmu Hukum. Bandung: Mandar Maju, 2008.

"Otoritas Jasa Keuangan." Accessed April 19, 2015. http://id.m.wikipedia.org/wiki/Otoritas_Jasa_Keuangan.

Pasaribu, Chairuman, and Suhrawardi K Lubis. Hukum perjanjian dalam Islam. Jakarta: Sinar Grafika, 2004.

Sabiq, Sayyid. Fikih Sunnah. Bandung: Al-Ma’arif, 1987. 
Soekanto, Soerjono, and Sri Mamudji. Penelitian Hukum Normatif: Suatu Tinjauan Singkat. Jakarta: RajaGrafindo Persada, 2006.

Umam, Khotibul. "Legislasi Fiqh Ekonomi Perbankan: Sinkronisasi Peran Dewan Syariah Nasional Dan Komite Perbankan Syariah.” Mimbar Hukum 24, no. 2 (June 2012).

Usman, Rachmadi. Produk Dan Akad Perbankan Syariah Di Indonesia, Implementasi Dan Aspek Hukum. Bandung: Citra Aditya Bakti, 2009.

Wiroso. Produk Perbankan Syariah, (Dilengkapi Dengan UU No. 21/2008-Perbankan Syariah Kodifikasi Produk Bank Indonesia. Jakarta: LPFE Usakti, 2009.

Peraturan Ketua Badan Pengawas Pasar Modal dan Lembaga Keuangan Nomor. PER03/BL/2007 tentang Kegiatan Perusahaan Pembiayaan Berdasarkan Prinsip Syariah

Ketentuan Penutup Fatwa DSN-MUI Nomor. 67/DSN-MUI/III/2008

Surat Edaran Bank Indonesia Nomor 10/14/DPbS, 16 Maret 2015, http://www.ojk.go.id/suratedaran-bank-indonesia-nomor-10-14-dpbs, 